\title{
NEW GENERATION CRAFT: IKEA HACK AND ITS TAXONOMY
}

\author{
Sena BERKTAŞ \\ İstanbul Gedik University, Turkey \\ sena.brk@hotmail.com \\ https://orcid.org/0000-0002-8439-4400 \\ Renk DIMLİ ORAKLIBEL \\ Bahçeşehir University, Turkey \\ renk.dimlioraklibel@arc.bau.edu.tr \\ https://orcid.org/ 0000-0003-2335-9895
}

\begin{abstract}
ABSTARCT
In this research, IKEA-hacks are examined according to their main characteristics and classified according to these examinations. In the study, IKEA-hack and Do-It-Yourself (DIY) and the IKEA Effect subjects are included to expose the IKEA-hack issue comprehensively. The IKEA-hacks examined in the classification were selected from the studies on the ikeahackers.net website. At first, a pilot study was carried out and a review table was created as a result of some improvements during the pilot study. The classification includes; the information about the intended use of products before and after the hack, to which hack category they belong to, how many IKEA products have been used in process, the instruments used in procedure, and which spaces the product has been prepared. The hack categories were divided into two main categories as visual and functional modifications. These modifications are discussed under 2 categories and 8 sub-categories. The first category is visual changes that includes only-colour modification (A), material change (B), colour and material change (C) as subcategories. The second category is dedicated to functional changes and includes sub-categories such as; the products used without any modification but for a purpose other than specified by IKEA (D), improved functionality (E), those with added functionalities $(\mathrm{F})$, modifications on the indented use specified by the company by making some modifications on the product $(\mathrm{G})$, and creating a new product by combining independent parts $(\mathrm{H})$. Among 6313 works presented on the ikeahackers.net website published between 2006 and 2018, 378 works involved in the sample were examined; the analyses were separately performed for every year and the changes were compared between the years. Examining the outcomes, only $21 \%$ of the practices were conducted for visual purposes only, $\% 79$ is about functionality. In visual based practices, category $\mathrm{C}$ comes front in which colour and material change performed at the same time. Whereas in the functional practices, people mostly performed Category $G$ in which hackers redefine the context of usage of the IKEA products.
\end{abstract}

Keywords: IKEA Hack, Do-It-Yourself, The IKEA-Effect, Alienation, Taxonomy

\section{YENI NESIL ZANAAT: IKEA-HACK VE SINIFLANDIRILMASI}

\section{ÖZ}

$\mathrm{Bu}$ araştırma kapsamında, yeni nesil zanaat olarak düşünülen IKEA-hack pratiği birçok yönüyle kapsamlı olarak ele alınmakta ve bu pratik kapsamında yer alan çalışmalar sınıflandırılmaktadır. Bu bağlamda IKEA-hack'in oluşumunu anlamamızı sağlaması açısından konunun Kendin-Yap ile ilişkisi, IKEA-Hack ve IKEA-hacker'lar, IKEA'nın neden hack'lendiğini açıklayan IKEA etkisi konularına da yer verilmiştir. Çalışma bölümünde ikeahackers.net web sitesinde yer alan IKEA-hack çalışmaları incelenmekte, bu çalışmalar özelliklerine göre sınıflandırılmaktadır. Hack kategorileri öncelikle görsel 
ve fonksiyonel değişimler olmak üzere ikiye ayrılmıştır. İlk temel kategoride sadece görsel değişimler yer almaktadır: Yalnızca renk değişimi olanlar (A), malzeme değişimi olanlar (B), renk ve malzeme değişimi olanlar (C). İkinci temel kategorinin altında da fonksiyonel değişim içeren örnekler yer almaktadır: Ürün üzerinde herhangi bir değişim yapılmadan doğrudan IKEA fïrmasının sunduğu kullanım senaryosu dışında kullanılanlar (D), işlevi arttırılan çalışmalar (E), farklı işlev eklenilenler (F), üzerinde bir takım değişiklikler yapılarak firmanın tanımladığı kullanımı biçimini değiştirenler (G) ve birbirinden bağımsız parçalar bir araya getirilerek yeni ürün oluşturanlar $(\mathrm{H})$. Ikeahackers.net adlı sitede 2006-2018 yılları arasında toplam 6313 çalışma yayınlanmıştır. Toplam küme içerisinden örnekleme 378 çalışma dahil edilmiştir. Örneklemdeki hack pratikleri incelenmiştir ve ortaya çıkan sonuçlar kapsamlı olarak değerlendirilmiştir. Öncelikle toplam uygulamaların \%21'inin görsel değişim amacıyla gerçekleştiği, \%79'unda ise fonksiyonel değiş̧im yapıldığı görülmüştür. Görsel değişimlerde en çok renk ve malzeme değişiminin birlikte yapıldığ $\mathrm{C}$ kategorisinde uygulama yapıldığ Fonksiyonel değişimlerde ise en çok $\mathrm{G}$ kategorisinde çalışma yapılırmış, ürünler firmanın tanımladığı kullanım bağlamından çıkarılmıştır.

\section{Anahtar Kelimeler: IKEA, IKEA Hack, Kendin-Yap, IKEA Etkisi, Yabancılaşma}

\section{INTRODUCTION}

Worker's conditions have witnessed great changes with the outset of the Industrial Revolution. Long before that, workers used to be responsible for the entire production of a certain product (Jensen, 1993). However, right after the revolution, the concept of fast production has emerged and altered the tasks undertaken by the workers who became responsible for only one part of the production, which required them to perform the same task repeatedly. In the new system, the workers have developed a sense of alienation at work due to the fact that they were not aware of the process for manufacturing the product as a whole, that in addition to their repetitive routine at work. At this point, an anti-alienation movement has emerged (Kohn, 1976; Toffler 1974: 52-54), which brought along the need to return to human-based activities that were common before the revolution (Wood, 2017: 85-92). Consequently, new trends emerged where people began to design and produce an entire product based on their needs. Among these prominent activities is The DIY movement, where people perform small projects such as, wall painting, building a dog kennel, renovating a kitchen, etc. These activities have continued to exist by diversifying until today (Campbell 2005, Atkinson 2006, Wolf and McQuity 2010). IKEA-Hack, which has emerged as an immensely popular activity in recent years, is similar to the DIY movement in that it includes designs performed through people's own desires and efforts. In this respect, it can be considered as a branch of the DIY movement. Within IKEA-hacking practices, people go beyond the usage patterns offered by IKEA company and hack the product. According to studies, people hack these products either as a hobby or to meet some of their needs. In addition, it is possible to make inferences about what people need in daily life and what solutions they seek through hacking. Detailing the IKEA-hack types would be helpful to comprehensive what people requires and how they find solutions.

To handle such a widespread creation systematically, it would be meaningful to examine and classify IKEA-hacks in detail. Thus, in this study, the IKEA hack practice is categorised according to the complexity and/or the depth (dedicated effort both mentally and physically) of the hack is considered. This way, it is aimed to reveal and state both the categories and to what extend do the hackers get involved in the hacking practice.

\section{IKEA-Hack and IKEA-Hackers}

Hack means to break, to break into pieces in English (dictionary.cambridge.org). The person who performs the act of breaking is known as a hacker (Eriş 2009). In general, the word of hack is associating with computers software systems (Stewen, 2003; McKenzie, 2004). Moreover, recently, the meaning of hacking evolved and included three dimensional objects (Richardson, 2016). At that point, maker culture, or maker movement, has been playing a significant role in stated change (Dougherty, 2012). Makers are people who make changes in technology-based objects. In another word, they hack three dimensional products. In this case, it is notable to highlight common points between IKEA-hackers and makers since they are creative, motivated, and resourceful people (Duman, 2020). Moreover, both maker culture and IKEA-hack requires changes on tangible or three-dimensional objects. 
IKEA-hack is defined as making changes on IKEA products by Jules Yap (2012), the founder of www.ikeahackers.net. According to her, with the action of hacking, it is aimed to bring a new function to the products, to disassemble and reassemble the parts, to improve the existing, to update, to customize and to reflect creativity. The people who carry out IKEA-hacking activities are called IKEA-hackers. IKEA-hackers make up a large group. The motivating factors for these individuals and activities have been the subject of investigation for many researchers (Rosner and Bean, 2009; Saakes 2009; Wang and Kaye, 2011; Tanenbaum et al., 2013).

\section{The IKEA Effect}

The IKEA Effect gives some ideas on why IKEA is hacked. In companies with a similar product scale with IKEA, frequently the purchase experience is like this: Customer gets in the store, likes a product, decides to buy it, pays for the product, go home, wait for the product to be brought home and installed by the company. In this case, the buyers are very passive, they do not play active roles. At IKEA, there is a system in which customers are more involved in the production of the product. Because it is expected to be installed by the user of the product purchased as a package. At this point, the concept of 'IKEA Effect' is mentioned (Norton et al., 2012).

The IKEA Effect is when people value the products, they make more than the readymade ones. This definition was introduced in 2012, along with IKEA's marketing strategies. Later, it was included in the research field of psychology, and studies in this scope appear in the literature (Hulten, 2012; Colombo, 2015). In the researches, it was found that the presence of the person's labour in the emergence of the product provides a more enthusiastic use of that product. In IKEA, the products are not sold as they are and suddenly appears in your house after purchase. There are some steps which push customers to have an active role. While shopping at IKEA stores, meters and small pens and note papers are often placed in showrooms. Assuming that the user knows the dimensions of his home, the dimensions of the products in the store are determined by measuring whether they are suitable for the customer's area. The user takes responsibility and takes action rather than asking the store staff for help and decides by measuring and examining the products. Customers are involved in the entire process; in the store they are responsible of selecting products, picking up parts of them in the store's depot, and transporting the product to their vehicle and to their home. And at home they open the packages, find the installation booklet, pay effort (both mentally and physically) to understand the instructions and apply them to experience the product they just bought.

The fact that the customers have control of the details of the product during the installation phase and being in close contact during the assembly of the parts, also directs them to be a potential IKEA hacker (Knott, 2013). It can even be claimed that IKEA has trained its customers with installation booklet with on design details, solutions, and knowledge in it. In Rosner and Bean's research (2009), hackers stated that they appreciate the aesthetics, packaging, and installation booklets of IKEA furniture and that they are facilitators in hacking projects. This form of studies appears in the hacks where people change the IKEA product (s) in line with their needs. In addition, without making a change to the product, IKEA can be hacked by just stripping from the context established by IKEA and defining a new context and usage form.

\section{The Method of the Study}

Examining IKEA-hacks on ikeahackers.net website, quantitative content analysis was preferred as a research method. On this method, all samples have same change for being examined and they are not affected each other's selection. Consequently, the selected examples did not repeat. To decide hack categories, a pilot study was performed. After the pilot study, the categories became clearer. All data were noted in an Excel table. The outcomes were presented by graphs. Evaluating the numerical data, the detailed explanations of IKEA-hackers about their practices on the website, strategy of IKEA and the features of its customer base were helpful for us. 


\section{Sample Creation}

Ikeahackers.net is a website founded by Jules YAP in 2006, where IKEA-hacking activities take place regularly (Figure 1).

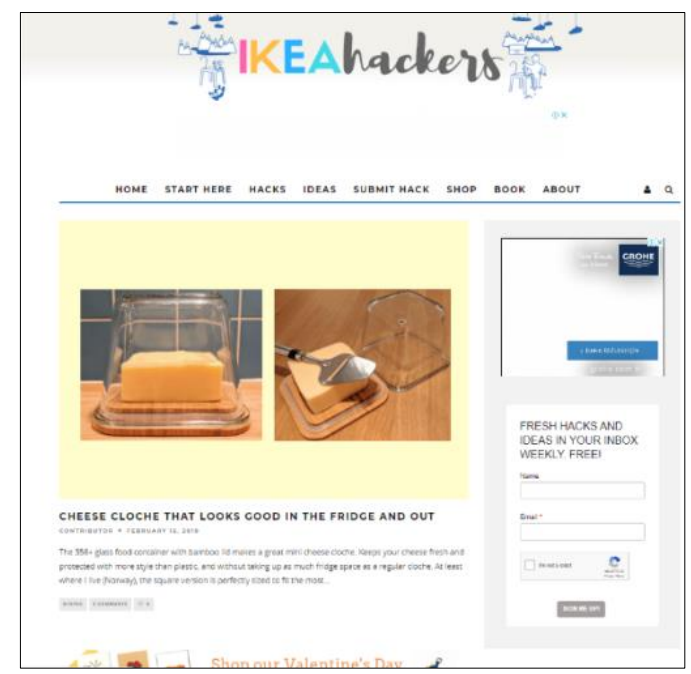

Figure 1. A screenshot from ikeahackers.net home page (Source: Ikeahackers.net / Access Date: $02.08 .2018)$

There are some reasons for choosing this website to use in the study. Firstly, one of the features that make the site privileged is that the submitted studies are examined and published afterwards. If the study applied as a result of the examination is similar to the previous ones, it is not published on the site again to prevent repetition. Another is the introduction of hacking suggestions for beginners from easy to complex, from work done in a flow (Figure 2). In addition, the website is structured in accordance with the description of the materials / products used in the name of a systematic transfer, the construction phase with visuals and written expressions.

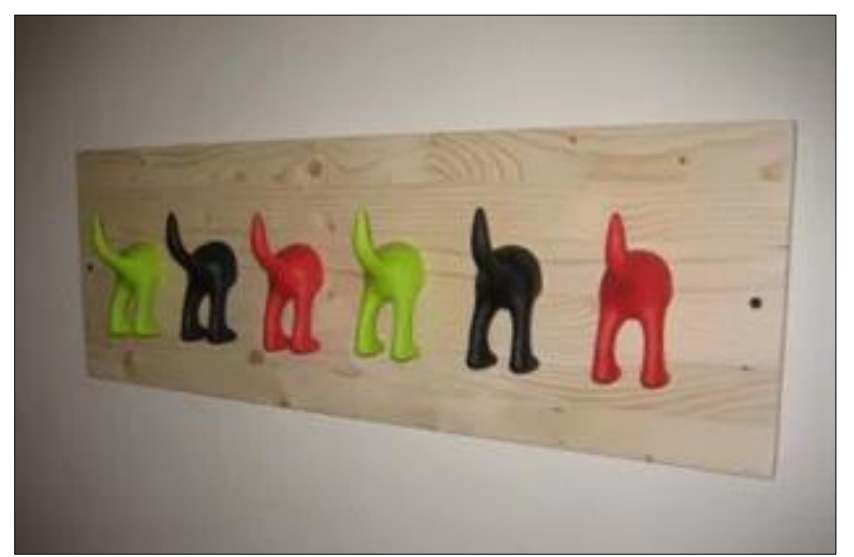

Figure 2. 'It's butts today' proposed hack at the beginner level. (Source: Ikeahackers.net / Access Date: 02.10.2018)

The necessary data were recorded by selecting among total of 6313 studies on the website between years 2006-2018. To select the adequate hacks from the total number in order to reach confidence interval, we define margin of error as 5\% and confidence level as $95 \%$ in the software. As a result of calculation, we need to select 378 hacks for the sample, which is almost $6 \%$ of the total hacks. However; the amount hacks were not distributed evenly in years, thus we pick $6 \%$ of total hacks from each year. The practices were not repeated, and all practices had equal possibility to be selected. In this context, a proportional

Research Article - This article was checked by iThenticate 
distribution has been provided for the scientific study for each year and the studies have been selected randomly.

As stated, 378 studies were included in the sample (Table 1), the necessary data were noted and analysed using the quantitative content analysis method. The data were noted numerically, and the findings were evaluated accordingly. In this scope, quantitative content analysis was found appropriate as a research method. This method was developed in 1950's with the requirement of method in mass communication studies at that period (White and Marsh 2006). The method has been using for studies which requires numerical calculations to select from aggregate data. Examining some part of practices from the website, this method was found useful to make adequate and necessary selection from total number. In total, 6313 practices were included on the website. Selecting the adequate practices from the total number, total number was noted as 6313, margin of error was $\% 95$ and confidence level was $\% 95$ in the software. As a result of calculation, the sample was created. The practices in the sample were selected randomly. The practices were not repeated, and all practices had equal possibility to be selected.

Table 1. Total number of hacks published in the website and the number of selected hacks between years 2006-2018

\begin{tabular}{|c|c|c|}
\hline Years & Total Hacks & $\begin{array}{c}\text { Hacks in the } \\
\text { Sample }\end{array}$ \\
\hline 2006 & 93 & 5 \\
\hline 2007 & 279 & 17 \\
\hline 2008 & 246 & 14 \\
\hline 2009 & 278 & 17 \\
\hline 2010 & 529 & 32 \\
\hline 2011 & 1366 & 82 \\
\hline 2012 & 1178 & 71 \\
\hline 2013 & 796 & 48 \\
\hline 2014 & 552 & 33 \\
\hline 20105 & 385 & 23 \\
\hline 2016 & 331 & 20 \\
\hline 2017 & 158 & 9 \\
\hline 2018 & 122 & 7 \\
\hline Total & 6313 & 378 \\
\hline
\end{tabular}

\section{Pilot Study:}

A pilot study was conducted before the main study was carried out. 2 studies were selected randomly from each year between 2006-2018. A total of 26 studies were examined and the necessary information was noted in a table. The table was revised for the main study as required. During the generation of the pilot table, basic information such as product title, date of upload and link of the product were indicated. Afterwards, a tab with the first and last usage purposes of the products is created in the table. The creation of the hack categories consists of several steps, it took its final form by changing each step. While creating hack categories, it is thought to be basically separated as visual and functional changes. In the literature, it is expressed in two different ways as visual and functional changes. However, it has been thought that there are many studies in ikeahackers.net and it will be insufficient to define them as studies that contain only visual and functional changes. Then, these definitions were intended to be expanded. The first table that appeared when designing hack categories in the pilot study is as follows (Table 2).

Table 2. Hack categories in pilot study, Version1

\begin{tabular}{|l|l|}
\hline Visual Changes & Functional Changes \\
\hline 1) Painting activities & 1) Increasing the functionality of the product \\
\hline 2) Covering activities & 2) Changing the intended use of the product \\
\hline
\end{tabular}

As it can be seen in Table 2, at first, visual changes are placed in two groups where products are generally painted with equipment such as brush, spray paint, and works where products are covered with leather, wood or any other form. Functional changes are examined into two groups in which the current usage

Submit Date: 15.08.2020, Acceptance Date: 02.12.2020, DOI NO: 10.7456/11101100/013

Research Article - This article was checked by iThenticate 
functions offered by IKEA (for example, adding a cover to the book shelf) and completely changing the intended use of the product (for example, creating a pet living space from the wardrobe with some operations on the product). Categorizing the practices, some of them were out of these definitions. Consequently, new steps were needed.

Table 3. Hack categories in pilot study, Version 2

\begin{tabular}{|l|l|}
\hline Visual Changes & Functional Changes \\
\hline 1) Painting activities & 1) Increasing the functionality of the product \\
\hline 2) Covering activities & 2) Changing the intended use of the product \\
& 2.a) Combining the product with a different main product \\
& 2.b) Joining the product with additional parts (e.g. shelf, foot, \\
cabinet door) & 2.c) Changing the purpose of use without any action on the product \\
\hline 3)Visual changes by adding products / \\
parts
\end{tabular}

The expression of visual and functional changes in Table 2 has been slightly changed. In addition to painting and covering processes, it was observed that visual changes were created in different ways. For example, in some studies, the foot part of the coffee table, dresser and similar products was replaced with the parts provided from outside. Thereupon, the definition of 'visual changes made by adding products / parts' was added to visual changes segment. Besides, it is observed that the changes in the use of products are created in many ways. Examining the practices on the website, options of combining the product with a different main product and adding different additional parts to the product were preferred for changing the purpose of use. Furthermore, although there was no practice on some products, the context of usage, thus the meaning of the product is changed by the hacking practice. With wide variety of studies, the content of the categories in the table above was tried to be expanded to define the existing studies more clearly.

Tablo 4. Hack categories in pilot study, Version 3

\begin{tabular}{|l|l|}
\hline Visual Changes & Functional Changes \\
\hline 1) Colour change only & $\begin{array}{l}\text { 1) Using for a different purpose without making changes } \\
\text { to the product }\end{array}$ \\
\hline 2) Material change only & \begin{tabular}{l} 
2) Adding a new functionality to the product \\
\hline 3) Colour and material change
\end{tabular} \\
\hline & $\begin{array}{l}\text { 3) } \\
\text { Changing the function of the product }\end{array}$ \\
\hline & 4) Creating a new product by combination of products \\
\hline
\end{tabular}

Table 4 included the phrases 'painting', 'covering' and 'visual changes made by adding products / parts' in visual changes. When there was such a definition, some studies could not be clearly defined. Colour change was intended to be expressed in the first step of visual changes, but it was defined as painting activities in the previous table. However, an object can be painted with the help of spray paint-brush or in any way, as we encounter in the works, by sticking a number of different materials such as fabric, paper, ribbon, peeling the product, polishing etc. it can change colour in many ways. For this reason, the statement of "colour change only" is offered instead of "painting processes". The reason for using 'only' is to prevent confusion when categorizing the practices.

In the second step of the visual changes, the expression "covering processes" was placed in Table 4. What was mentioned at that point was the change in the basic material of the products. For example, in one study, the top of the console was replaced by a different wooden table. In this example there has been a change in the material of the product, but not by means of the covering. Change through covering was thought to be just one of the processes of material change. Thus, the phrases 'coating processes' and 'material change' have been replaced. It was thought that it would be more appropriate to include definitions that include all colour changes and all material changes, rather than expressing visual changes as painting-covering issues and visual changes made by adding products / parts. In addition, studies involving colour and material changes were added as the third subtitle of visual changes. 
Functional changes also were rearranged to allow direct matching of each product and category. In Table 4 , the hacking categories are arranged in their proximate form. In this way, each of the products in the pilot study matched and accurately and clearly defined.

\section{Categorization of IKEA-hacks}

With the help of initial product use and last product use section, the hack categories are examined. Data on initial product use and last product use help us categorize hacks.

In the table, according to the way the practice is carried out, the category it belongs to is determined and the relevant box is marked. Each of the studies must be in one of the categories. Hack categories are basically divided into 2 groups, visual changes in the first group, and functional changes in the second group.

A, B, C categories constitute the first group and D, E, F, G and $\mathrm{H}$ categories constitute the second group (Table 5). Category A refers only to the colour changes on the product. This first category generally includes the simplest changes among the studies.

Tablo 5. Hack categories and explanations

\begin{tabular}{|c|c|c|}
\hline \multirow{3}{*}{ 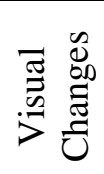 } & A & only colour change \\
\hline & B & only material change \\
\hline & $\mathrm{C}$ & colour and material change \\
\hline \multirow{5}{*}{ 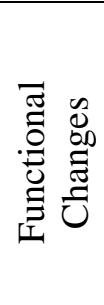 } & $\mathrm{D}$ & using the product for a different purpose without any change on it \\
\hline & $\mathrm{E}$ & enhancing the usage of the product \\
\hline & $\mathrm{F}$ & adding an extra functionality to the product \\
\hline & G & changing the function of the product \\
\hline & $\mathrm{H}$ & creating a new product by combination of materials \\
\hline
\end{tabular}

Some practices have changes in different colours generally with spray or wood paints. These practices included in category A.

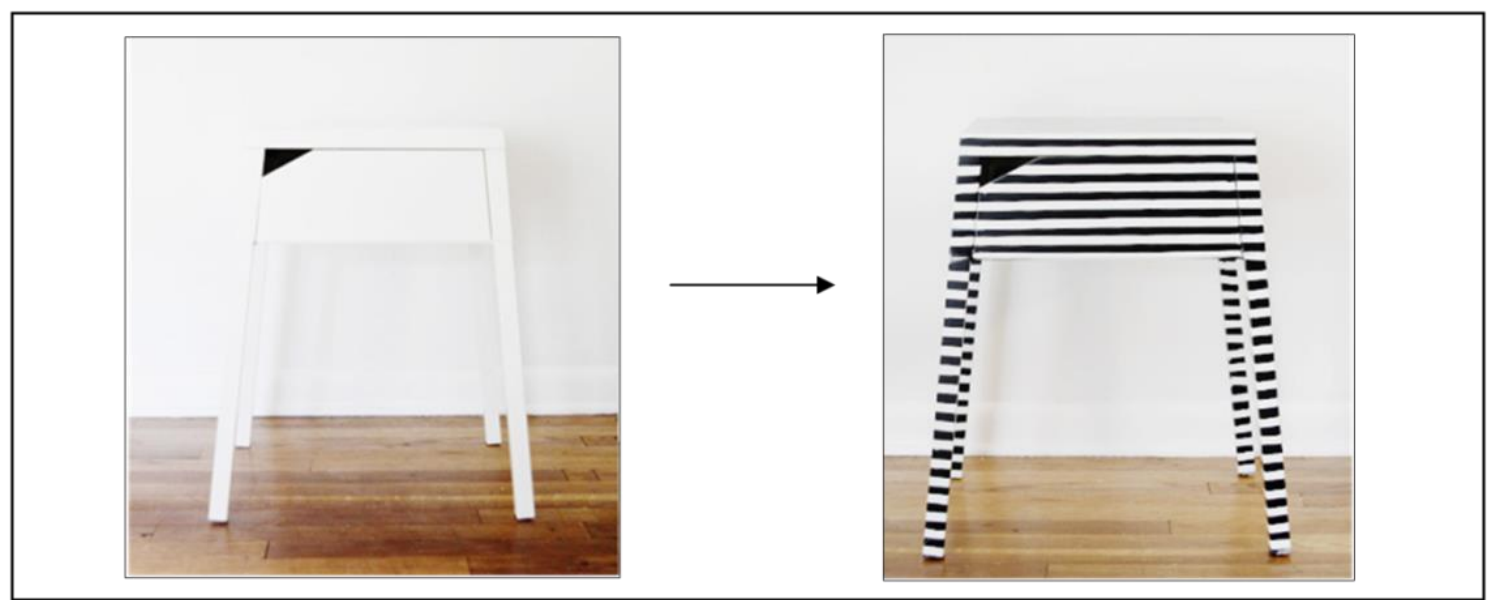

Figure 3. Example hack of category A (Source: Seekatesew.com / Access Date: 02.03.2019)

Figure 3 is an example of category A (original image on the left, painted on the right) as there is only a colour change on the product. This kind of practices have been seen frequently in home-textile products also such as Bold Painted Rug-2011, Mod Pink Geometric Painted Erslev Rug-2011; people colour and pattern their plain curtains and carpets on these practices. Since there are only colour changes, the practices were noted in category A. 
In category B, there are material changes on the products (Figure 4). People cover their objects, alter some of parts with another material etc.

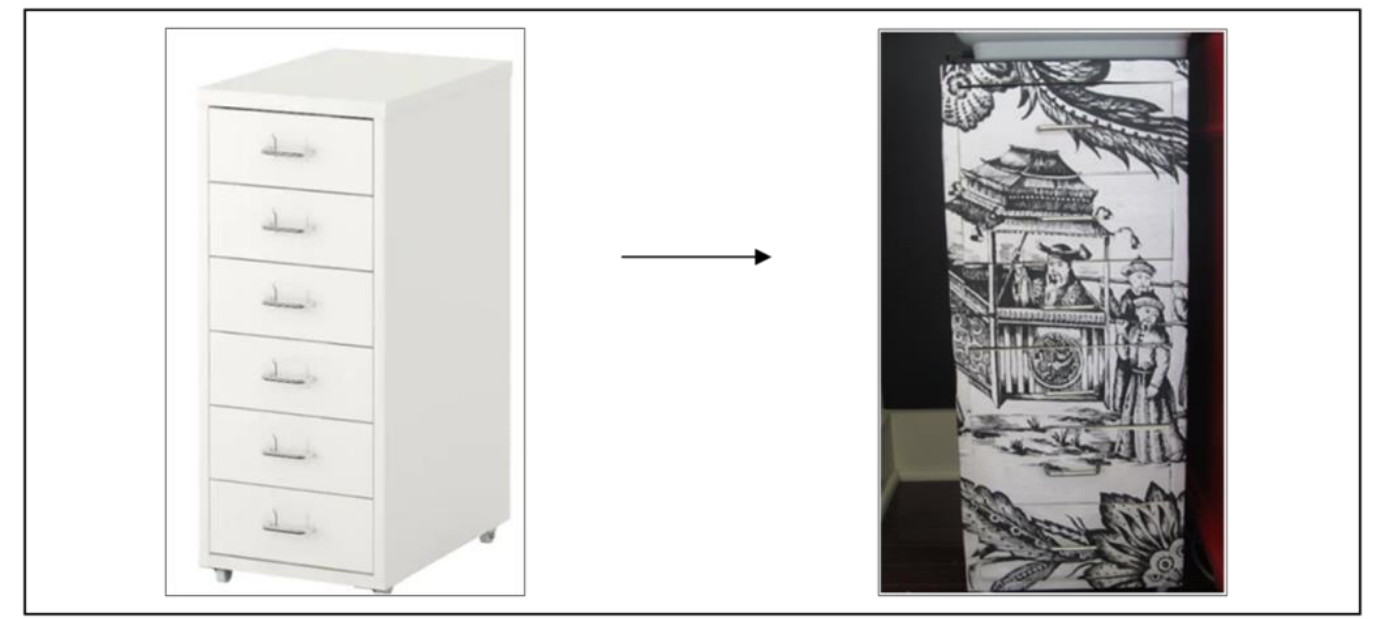

Figure 4. Example hack of category B (Source: Ikeahackers.net / Access Date: 09.02.2019)

IKEA-hackers often do some great changes on their products like in picture. In category C, people perform colour and material change at the same time for visual renovations.

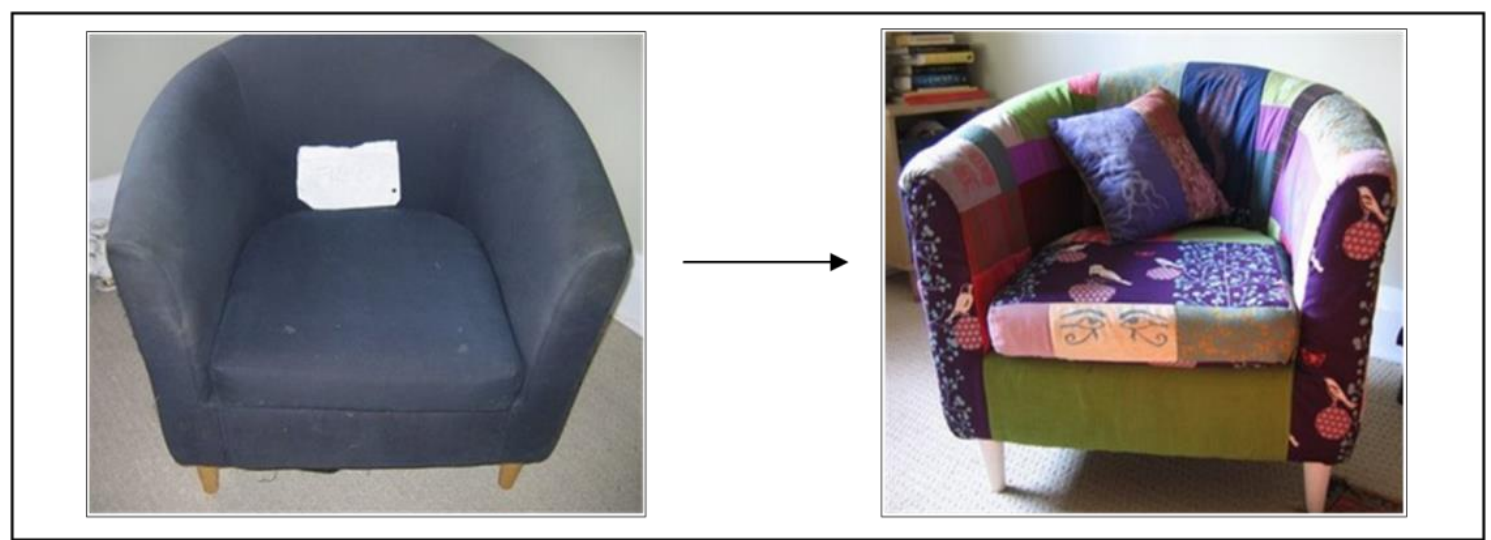

Figure 5. Example hack of category C (Source: Ikeahackers.net / Access Date: 02.07.2019)

In Figure 5, the TULLSTA seat is covered with another fabric. The legs are changed from the natural colour of the wood to white. It was included in category $\mathrm{C}$ because there was both covering (material change) and painting in the study.

The studies in the second group are those in which some functional changes and improvements come to the fore. Although there are some visual touches from time to time in these studies, it is thought that functional changes are ahead of visual processes, and such studies are included in the second group. For example, if there is both a colour change and a new function in a study, this study is directly evaluated in the second category.

It is possible to consider the studies that constitute the category $\mathrm{D}$ as the simplest hacks of the second group, these studies are used directly outside the usage scenario presented by IKEA company without any change on the product. The use of a flowerpot as a pencil holder and the positioning of the bathroom cabinet as an office cabinet are examples of IKEA products being included in daily life outside of their intended purpose. 


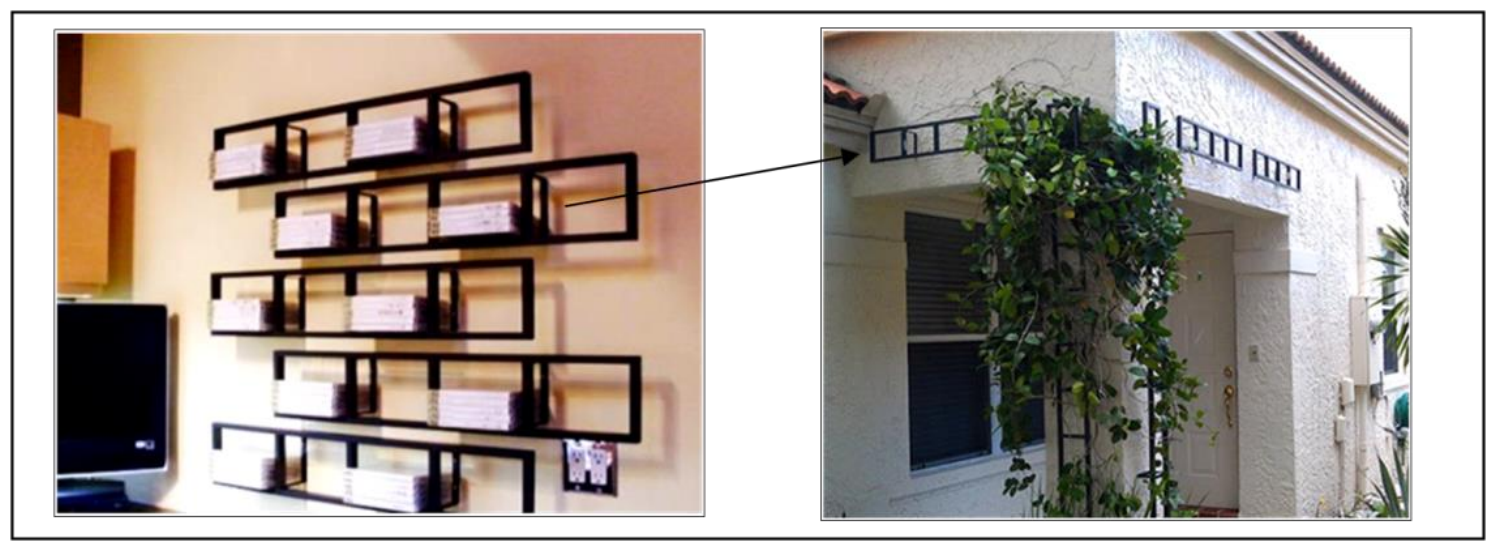

Figure 6. Example hack of category D (Source: Ikeahackers.net / Access Date: 19.02.2019)

In Figure 6, the LERBERG DVD / CD shelf is used for plants on the outer wall of the building.

The next one, category E contains additions that can also be defined as increasing their function; studies in which the features that already exist in the product itself are marginally increased according to the need can be seen in this category.

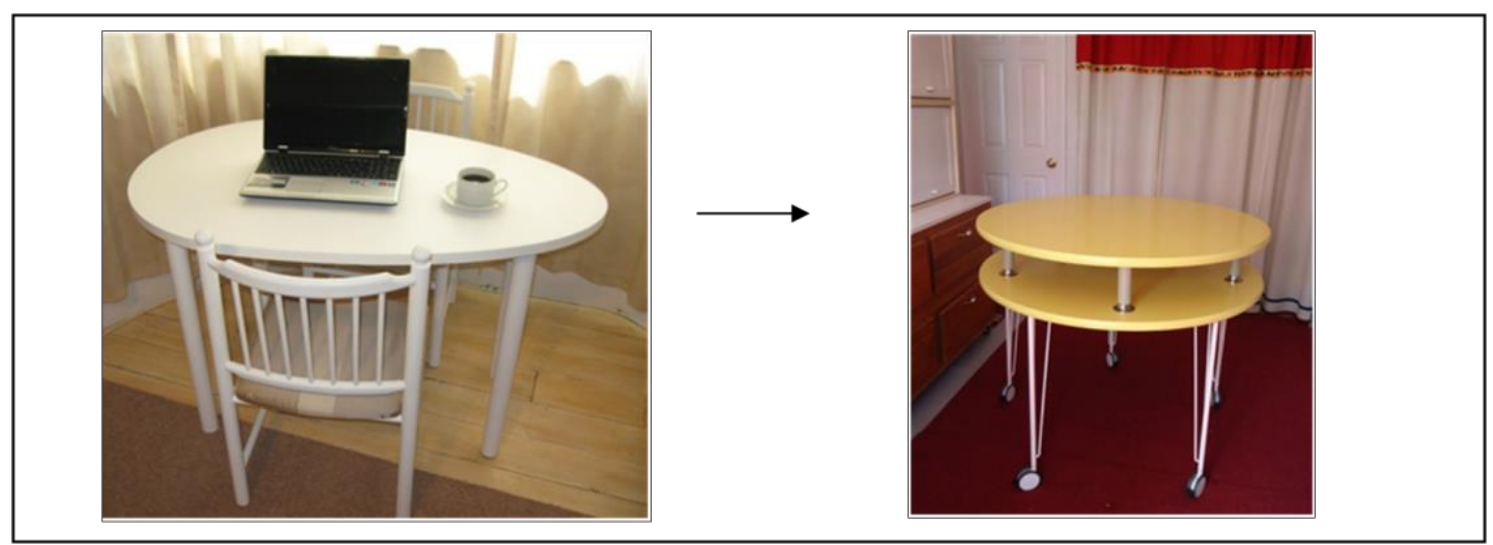

Figure 7. Example hack of category E (Source: Ikeahackers.net / Access Date: 03.04.2019)

Figure 7 shows an example of the general use of the desk in daily life. The product on the right appears as a hacked version of a different colour of the same product. In the new design, another wooden part has been added to the table. The IKEA-hacker stated that he made such an addition because the table was suitable for standing use. The product is still used as a table. However, it has acquired an additional function to be able to work standing and is included as an appropriate example in the E category. Increasing the number of shelves of a bookshelf, lowering the height of a high bed, and producing products that offer better functionality to the person are included in this category.

Moving to another section which is category $\mathrm{F}$, the product basically performs the task given to it by the company but has also acquired several different functions.

Research Article - This article was checked by iThenticate 


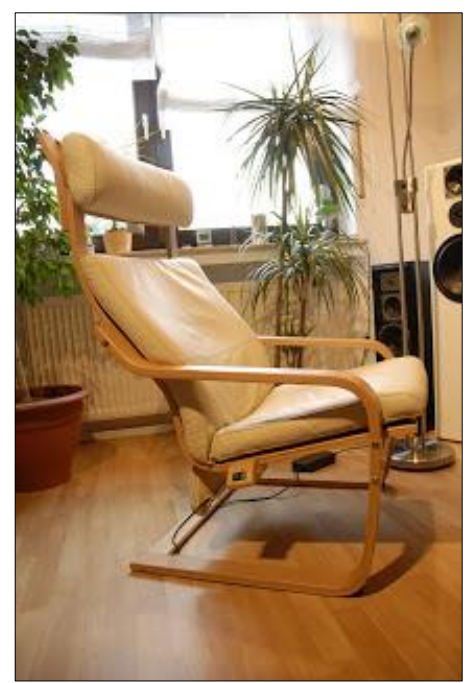

Figure 8. Example hack of category E (Source: Ikeahackers.net / Access Date: 11.03.2019)

Figure 8 is an example for category F; An ordinary seating element was inspired by the feature in the seat of Mercedes Benz and added a heater. This product is still a sitting element and it is also used in daily life as a heated seating element. As an example, chancing an ordinary electric lamp to a working condition with solar energy could be evaluated in this group since it requires technology attachment.

The seventh is the category $\mathrm{G}$, the product has gone beyond the defined task. The product defined by IKEA in a specific way has been used in a different place and in a different way according to the needs and wishes of the user (unlike category D, the product is not directly used in a different place as it is, it requires some work on it).The product in category $\mathrm{G}$ greatly have been changed. There is no connection between the usage of the product before and after.

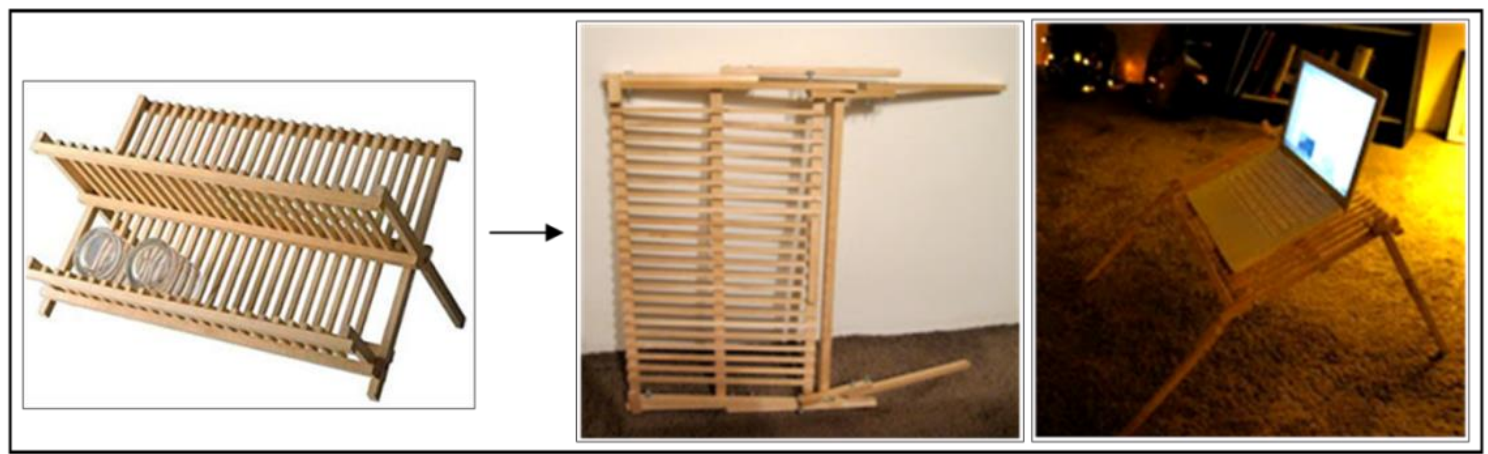

Figure 9. Example hack of category G (Source: Ikeahackers.net / Access Date: 05.06.2019)

In Figure 9, the BAMBU dish rack has been reconfigured and turned into a laptop stand.

The final one, category $\mathrm{H}$ means the combination of independent parts to create a new product.

In this category, the parts that make up the product are basically independent of the product, they are not generally related to the last product, they come together to form a meaningful whole.

Research Article - This article was checked by iThenticate 


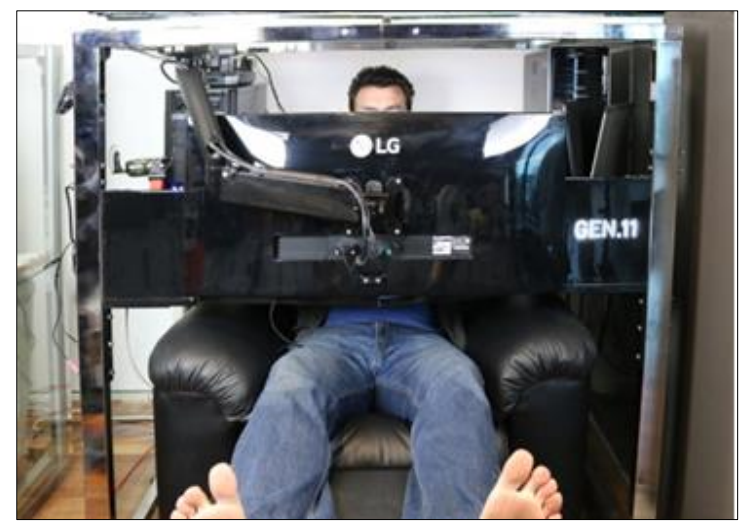

Figure 10. Example hack of category H (Source: Ikeahackers.net / Access Date: 03.03.2019)

In Figure 10, a home theatre-game system was created by combining 2 tables + armchairs + shelving unit + support and connection elements. Although the parts used to design the work make no sense alone, they have formed a meaningful product. Another example for this category is 'How to Make a Woodgrain Magnetic Memo Board and Tool Storage' from 2011. An IKEA-hacker created a pinboard with combining magnetic board, penholder, containing for storing knives and some other materials.

\section{FINDINGS}

After these categories of IKEA hacks are defined, the 378 hacks that are in our sample is examined and placed one of in these categories, in yearly basis. Moreover, in the excel document we write down the intended product type defined by IKEA, the after-hack product type, how many IKEA products are used, and 3-scaled complexity of the tools used to realize the hack data are noted (Figure 11).

\begin{tabular}{|c|c|c|c|c|c|c|c|c|c|c|c|c|c|c|c|c|c|c|c|}
\hline \multirow{2}{*}{ Name } & \multirow{2}{*}{ First usage } & \multirow{2}{*}{ Last Usage } & \multicolumn{8}{|c|}{ Hack Categories } & \multicolumn{4}{|c|}{$\begin{array}{l}\text { IKEA Product } \\
\text { Usage }\end{array}$} & \multicolumn{4}{|c|}{ Tool Usage } & \multirow{2}{*}{$\begin{array}{c}\text { Prouct } \\
\text { Categories }\end{array}$} \\
\hline & & & A & B & c & D & E & $\mathbf{F}$ & G & $\mathrm{H}$ & P1 & P2 & P3 & $\mathrm{NI}$ & $\mathrm{T} 1$ & T2 & T3 & NI & \\
\hline DIY a Mercury Glass Lamp wi & lamp & lamp & & & 1 & & & & & & & 1 & & & 1 & & & & lighting \\
\hline CASUAL FRIDAY OFFICE & $\begin{array}{l}\text { drawer+shelving } \\
\text { unit+wooden table }\end{array}$ & table & & & & & & & & 1 & & & 1 & & & & & 1 & working area \\
\hline VARIERA shelf insert to bathr & shelving unit & shelving unit & & & & & & 1 & & & 1 & & & & & & & 1 & living room \\
\hline Double SOCKER pendant lam & $\begin{array}{l}\text { lamp cable+ } \\
\text { clothes }\end{array}$ & lamp & & & & & & & & 1 & & & 1 & & & & & 1 & lighting \\
\hline Transforming a living space - & $\begin{array}{c}2 \text { bookcase+ } \\
\text { wardrobe }\end{array}$ & TV unit & & & & & & & & 1 & & & 1 & & & & & 1 & TV-cabinet systems \\
\hline DIY Card Catalog / Apothecar & commode & commode & & & 1 & & & & & & 1 & & & & & & & 1 & bedroom \\
\hline DUNSÖN Drying Rack & shopping cart & clothes hanger & & & & & & & 1 & & 1 & & & & & & & 1 & other \\
\hline TV hench with a nersonal toul & TV unit & TVunit & & & & & & & & & 1 & & & & & & & 1 & thinet sve \\
\hline
\end{tabular}

Figure 11. Screenshot from the excel document created for the research, some hacks from 2015

Table 6 shows the percentage change of IKEA-hacks between 2006-2018. It is visible that, throughout the years, category G, in which both context and the product is hacked, is dominant amongst all hack types. Category $\mathrm{G}$ is followed by $\mathrm{H}$, where hackers combine different parts together to reach a unique product. These two categories of hacks are the ones considerably more difficult both by means of complexity of the newly created product and tools used in order to create that hack. In general, we can say that the functional hacks are actualized more than visual hacks. At that point we need to underline that category $\mathrm{D}$, where the product is kept as it is but the context of usage has changed, is the least preferred hack.

Table 6. Percentage rate table of hacking categories between 2006-2018

\begin{tabular}{|c|c|c|c|c|c|c|c|}
\hline $\mathbf{A}$ & $\mathbf{B}$ & $\mathbf{C}$ & $\mathbf{D}$ & $\mathbf{E}$ & $\mathbf{F}$ & $\mathbf{G}$ & $\mathbf{H}$ \\
\hline $5,4 \%$ & $6,7 \%$ & $9 \%$ & $4 \%$ & $15 \%$ & $12,4 \%$ & $28,25 \%$ & $19,2 \%$ \\
\hline
\end{tabular}


The study is generated yearly basis to make the changes in the categories visible in time. Comparing the groups (Figure 12), while studies in category $\mathrm{G}$ were prominent in previous years $(2006,2008,2010$, 2011), in the following few years $(2014,2015)$ studies belonging to category $\mathrm{H}$ were prevalent. Recently, categories E and G contain high rates. However, unlike other years, in 2007 and 2017, mostly visual works were seen. Practices in category A were performed less than other types of studies in all periods.

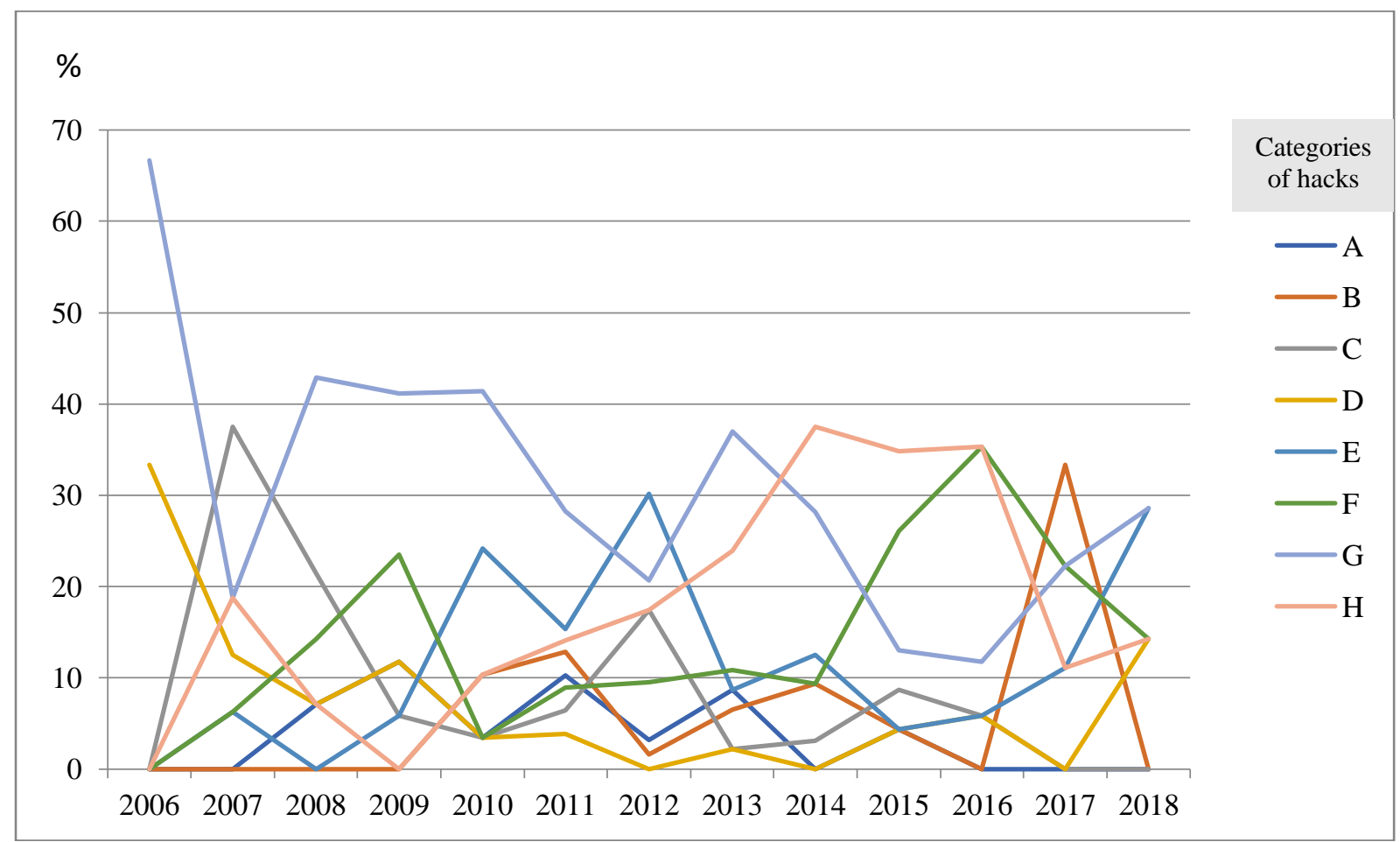

Figure 12. Percentages of IKEA-hacks between 2006-2018

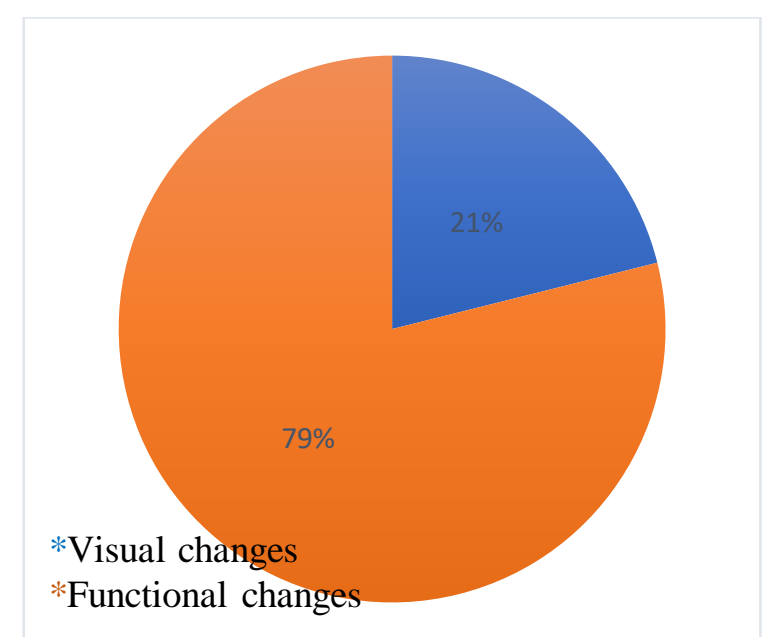

Figure 13. Percentages of visual and functional changes in total number

Before the hacks were evaluated in the context of the category, hacks were discussed in terms of visual and functional changes (Figure 13). Visual changes are less common than hacks with functional studies. According to the data in Table 6 and Figure 12, studies in the second group were more prominent than the first one. In the period from 2006 to 2018, functional change was at the forefront in approximately $69 \%$ of the studies, and just approximately $21 \%$ of the hacks contain only visual changes. Considering all the years together, most studies were conducted in $\mathrm{G}$ in total which means people needed or preferred

Research Article - This article was checked by iThenticate 
to change the current functions of the products in their practices. It follows that category H. Figure 12 can be interpreted in different ways. Considering all years together, the difference between visual and functional changes in terms of number is quite striking, there are usually functional changes in the work of hackers. One of the reasons why the visual changes are much less may be that IKEA's existing designs are already sufficiently admired, and people avoid deterioration of the original design. Another reason: It may be that people want to use their time in a way that has more benefit considering the IKEA Effect. They might be in search of more challenging hacks in order to increase their hedonic experience, so they are less interested in only visual changed practices. Examining the visual changes, studies with material and colour change together were most performed (category C), and the studies containing only colour change were the least (A). In some studies, among these, there are only material changes. According to Figure 12 and Table 6, we can comment that when hackers want to make visual changes in their products, they are not satisfied only the most basic activities such as painting, but they apply material and colour change together. In this case, it can be interpreted that a wide variety of materials can be used when making visual changes in a product, different visualization issues are preferred in different parts of the product / visual changes are clearly applied on the product (such as covering the fabric of the seat and painting the feet). Examining functional changes in Table 6, the number of studies in the G category is higher than the others. Among the reasons why the studies in this category come to the fore, it may be easier for them to transform a product on the market than to produce something new with materials when they will reveal a product that is created in one's imagination - designed from scratch in his mind. For example, a person who wants to watch a movie in bed has a device in his mind, such a product is not common in the market. Instead of creating the product from beginning, the person transformed a product in IKEA according to this need ('Dahl Vader' Home Theatre Gaming Workstation Boss Chair2016). Looking at the other categories where functionality is important, category $\mathrm{H}$ follows category $\mathrm{G}$. Next comes the E category and the F category. Category D is quite in the background compared to the others in terms of number.

There are not too many differences in number between categories $\mathrm{H}, \mathrm{G}$ and E. Consequently, it was not meaningful to evaluate it in terms of number and it will be examined one by one. In category $\mathrm{H}$, coming together of independent parts and meeting the needs of the person are the works that provide the most flexibility to IKEA hackers, quite different combinations can be obtained with independent parts. Lack of limitation can make that kind of activities more enjoyable. It is possible to create many desired items and to meet many needs by collecting individual pieces. Besides, people may also want to evaluate their unused objects. Useless objects can meet the needs of the user by coming together with others.

Category E hacks are an effective way to adapt the existing product to the needs of the person. As in many studies, it may be the case that the people cannot find the product that fully meet their needs in the market, and they look for solutions. To meet their needs, it can be easier to modify the existing product than to make a product or to have it made by carpenter. Among the hacks examined, there are studies such as changing the size of the library by the customer with a pitched roof, bringing the shoe rack of someone with a duplex house to the same height as the staircase, shortening the feet of the bed etc.(ikeahackers.net). In this section, creative hacks are not seen very often, but the examples are still a very efficient way to change / use the existing product more effectively according to the customer's personal characteristics and living needs.

Practices in category F are basically used as defined by the company and include studies in which some functions are also added. Figure 8 shows that it was designed for the warming need especially during the winter months and will allow to more comfortable winter. In a study on Ikeahackers.net, a baby changing section was added to the closet in the baby room, one of the shelves is now used as a baby changing place. The IKEA-hacker may have done this work to use the space efficiently due to the small size of the room or may not have wanted to spend extra money on a new baby changing area. Technology integration also stands out in some of the studies in this category (for example, creating a 3D printer by combining several LACK tables / A 3D Printer Framework Never Looked so Good-2016). In many studies on Ikeahackers.net, technology is used in some of these functions when an additional function 
is needed (benefit from light, heat, solar energy, etc.). Briefly, although the studies placed in the F category have similar purposes with other hacks, it can be said that they create the need to add extra functions to an existing product and meet the needs of many people.

Among all studies, practices in category D were performed the least. There are many reasons why this category gets behind: People may not think of ideas about applying directly to another area without making any changes on the product since this kind of practices requires more flexible thinking, the idea of applying it to a different area without making changes on the product may seem restrictive for hackers or may not make them feel their creativity. For similar reasons, category D may be left behind in hacks. However, category D requires the most creative thinking and the most original hacks are seen in this group.

\section{CONCLUSION}

There are many IKEA-hack practices on online platforms. IKEA-hacks are evaluated as visual and functional studies in the literature. In this study, the practices in ikeahackers.net were examined and detailed. Hacks have been examined in 8 categories: Category A / only colour change on the product, category B / only material change, category C / colour and material change, category D / using for a different purpose without any change on product, category E / enhancing the usage of the product, category F / adding extra functionality, category G / changing the function of the product, category $\mathrm{H}$ /creating a new product by combination of materials. In the literature, it has been stated that studies with only visual changes are not important and it has been emphasized that studies providing functional benefits are more noteworthy (Rosner and Bean, 2009). The hacks in the sample also confirm this criticism. Only $21.1 \%$ of the practices were conducted for visual purposes only, \%79.9 is about functionality. Examining the categories, there are more studies in which colour and material change in visual-based studies. In this case, it can be thought that people need large-scale visual changes instead of small touches. The reason for visual studies can be many situations such as changing trends, the need for change in the person over time, obtaining a new look for old objects.

In functional studies, most studies were conducted in the G category in total number. Although it is not easy to work in this category, people conduct this kind of studies. It seems that people are looking for solutions to some of their needs and somehow modify the product they have. Also it should be stated that the hedonic outcome of overcoming a difficult hack is much higher than an easier one, following the IKEA Effect. Category D stayed behind in functional studies. The reasons for this may be that the context is presented strong enough and cannot be detached from it, and IKEA already provides the user with the features such as modularity / flexible use of products. It can also be the possible that creating a $\mathrm{D}$ category of hack, keeping the product as it is but changing all the context, may need a different type of skill. Since the hacker needs to conceptualize the object in a totally new way of usage.

Noting the data year by year, while category $G$ were prominent in previous years $(2006,2008,2010$, 2011), practices in category $\mathrm{H}$ were prevalent in 2014 and 2015. In the last period, categories $\mathrm{E}$ and $\mathrm{G}$ have high rates. In 2007 and 2017, mostly visual practices were placed in total number. However, Category A was in the background in all periods.

\section{REFERENCES}

Atkinson, P. (2006). Do it yourself: Democracy and design. Journal of Design History, 19(1), 1-10.

Campbell, C. (2005). The craft consumer: Culture, craft and consumption in a postmodern society. Journal of Consumer Culture, 5(1), 23-42.

Colombo, B., Laddaga, S., \& Antonietti, A. (2015). Psychology and Design. The Influence of the Environment's Representation Over Emotion and Cognition. An ET Study on Ikea Design. Procedia Manufacturing, 3, 2259-2266.

Dougherty, D. (2012). The maker movement. Innovations: Technology, governance, globalization, 7(3), 11-14. 
Duman, S. (2020). Integration of Hacking Mindset and Practice to Industrial Design Education. Online Journal of Art and Design, 8(2).

Eriş, U. (2009). Türkiye'de Kırıc1 (Hacker) Kültürü. PhD thesis. Eskiş̧ehir: Anadolu University

Hultén, B. (2012). Sensory cues and shoppers' touching behaviour: The case of IKEA. International Journal of Retail \& Distribution Management.

Jensen, M. C. 1993. The modern industrial revolution, exit, and the failure of internal control systems. The Journal of Finance, 48(3), 831-880.

Knott, S. (2013). Design in the age of prosumption: The craft of design after the object. Design and Culture, 5(1), 45-67.

Kohn, M. L. (1976). Occupational structure and alienation. American Journal of Sociology, 82(1), 111-130.

McKenzie, W. (2004). A hacker manifesto. President and fellows of Harvard College.p:71

Norton, M. I., Mochon, D., \& Ariely, D. (2012). The IKEA effect: When labor leads to love. Journal of Consumer Psychology, 22(3), 453-460.

Raymond, E. S. (2003). How to become a hacker. Database and Network Journal, 33(2), 8-9.

Richardson, M. (2016). Pre-hacked: Open Design and the democratisation of product development. New Media \& Society, 18(4), 653-666.

Rosner, D., \& Bean, J. (2009, April). Learning from IKEA hacking: I'm not one to decoupage a tabletop and call it a day. In Proceedings of the SIGCHI Conference on Human Factors in Computing Systems (pp. 419-422).

Saakes, D. (2009, October). Big lampan lamps: designing for DIY. In Proceedings of the seventh ACM conference on Creativity and cognition (pp. 403-404).

Tanenbaum, J. G., Williams, A. M., Desjardins, A., \& Tanenbaum, K. (2013, Nisan). Democratizing technology: pleasure, utility and expressiveness in DIY and maker practice. SIGCHI Conference on Human Factors in Computing Systems içinde (ss. 2603-2612).

Toffler A., (1974, pp.52-54). Şok. İstanbul: Koridor Publishing house

Wang, T., \& Kaye, J. J. (2011). Inventive leisure practices: understanding hacking communities as sites of sharing and innovation. In CHI'11 Extended Abstracts on Human Factors in Computing Systems (pp. 263-272).

White, M. D., \& Marsh, E. E. (2006). Content analysis: A flexible methodology. Library trends, 55(1), $22-45$.

Wolf, M., \& McQuitty, S. (2010) Understanding the do-it-yourself consumer: DIY motivations and outcomes. AMS Review, 1(3-4), 154-170.

Wood, A. (2017, pp. 85-92). Karl Marx. İstanbul: İletişim Publications (original edition:2004)

Yap, J. (2012). Finding Your Way Around Ikeahackers, Https://www.ikeahackers.net/start-here. Access Date: 12.032019

Research Article - This article was checked by iThenticate 